\title{
PRIMER NOTE Polymorphic microsatellite loci in Allodapine bees for investigating the evolution of social behaviour
}

\author{
PHILIPP LANGER,* DRUDE MOLBO*† and LAURENT KELLER* \\ Department of Ecology and Evolution, University of Lausanne, Biology Building, 1015 Lausanne, Switzerland
}

\begin{abstract}
Allodapine bees provide extraordinary systems for investigating the evolution of cooperation and particularly the division of reproduction in animal societies. We present the first microsatellite primers for two native Australian species (Exoneura nigrescens and E. robusta; Hymenoptera: Apidae: Xylocopinae) which allow the accurate determination of pedigrees, reproductive skew and relatedness in colonies. Up to 55 different alleles were observed per locus.
\end{abstract}

Keywords: Allodapine bee, Exoneura nigresecens, Exoneura robusta, Microsatellites, Reproductive Skew

Received 20 December 2003; revision received 28 January 2004; accepted 25 February 2004

Allodapine bees form a tribe in the subfamily Xylocopinae (family Apidae). They range from nonsocial to highly social species, displaying great diversity in levels of sociality (Schwarz et al. 1998). This makes them ideal for comparative investigations of the evolution of social behaviour. Several species are facultatively eusocial, and whole colonies can often be transferred between experimental plots differing in a given ecological parameter (e.g. Cronin 2001). These properties give unrivalled opportunities for testing models of the evolution of reproductive skew (Reeve \& Keller 2001), provided genetic relationships within nests can be inferred. Codominant multiallelic markers such as microsatellites are the best tools for this task (Gerber et al. 2000), and we therefore have developed primers for 13 highly variable microsatellite loci in two Allodapine species, Exoneura nigrescens and E. robusta.

We extracted DNA from the thorax of Exoneura nigrescens and E. robusta specimens collected from two sites in Victoria, southeastern Australia (Cronin 2001) using a phenol-chlorophorm protocol (Estoup \& Turgeon 1996). DNA was digested with AluI, HaeIII and RsaI; fragments within the 200-800 bp range were ligated into pUC18 plasmids and used to transform Epicurian Coli XL1-Blue

+Present address: Smithsonian Tropical Research Institute, Apartado 2072, Balboa, Republic of Panama, and Institute of Cell, Animal \& Population Biology, University of Edinburgh, King's Buildings, Edinburgh EH9 3JT, Scotland UK

Correspondence. Philipp Langer. Fax: + 4121 692-4165; E-mail: Philipp.Langer@ie-zea.unil.ch
MRF' supercompetent cells (Stratagene, Amsterdam, the Netherlands). Some 6000 positive clones per species were replated on grid Petri dishes and screened for the microsatellite motifs $(\mathrm{AAT})_{10^{\prime}}(\mathrm{TC})_{10^{\prime}}(\mathrm{TG})_{10}$ and (GGA) ${ }_{8}$ using a digoxygenin nucleic acid detection kit (Boehringer Mannheim, Basel, Switzerland). Plasmids from 310 positive clones were cycle sequenced using BigDye ${ }^{\mathrm{TM}}$ chemistry (Applied Biosystems, Foster City, USA) and analysed on an ABI PRISM 377XL DNA sequencer (Applied Biosystems). Primers were designed using GENEFISHER 1.3 (Giegerich $e t$ al. 1996), and PCR conditions were optimized for fluorescently labelled primers and electrophoresis on an ABI 377XL sequencer. A total of 63 sequences (24'153 bp; 38 for Exoneura nigrescens, 25 for E. robusta) containing microsatellite motifs from two to eight basepairs are published on GenBank under the accession numbers AY222377 to AY222439. Primer pairs for 13 of the most variable loci are shown in Table 1. Cross amplifications between E. nigrescens and E. robusta were possible for all loci.

For routine genotyping, DNA was extracted from whole individuals using a modified salt protocol. In brief, samples were frozen in liquid nitrogen, ground with a pestle and digested overnight at $55^{\circ} \mathrm{C}$ in $300 \mu \mathrm{L}$ extraction buffer (50 mm TRIS HCl, 1 mm EDTA, $0.1 \mathrm{M} \mathrm{NaCl}, 1 \%$ SDS, $8 \mathrm{mg}$ / $\mathrm{mL}$ DTT, $0.4 \mathrm{mg} / \mathrm{mL}$ Proteinase K). Denatured proteins were precipitated with $150 \mu \mathrm{L} \mathrm{NaCl} 4.5 \mathrm{M}$ and extracted using $450 \mu \mathrm{L}$ chloroform-isoamylalcohol (24:1), then DNA was precipitated with $250 \mu \mathrm{L}$ isopropanol, washed with $500 \mu \mathrm{L} 80 \%$ ethanol and resuspended in $100 \mu \mathrm{L}$ or $50 \mu \mathrm{L} \mathrm{ddH_{2 }} \mathrm{O}$ (E. nigrescens and E. robusta, respectively). 
Table 1 Characteristics of microsatellite markers for Exoneura ssp

\begin{tabular}{|c|c|c|c|c|c|c|c|c|}
\hline \multirow[b]{2}{*}{ Locus $^{(1)}$} & \multirow[b]{2}{*}{$\begin{array}{l}\text { Core } \\
\text { repeat }^{(2)}\end{array}$} & \multirow[b]{2}{*}{$\begin{array}{l}\text { Product } \\
\text { size }^{(2)}\end{array}$} & \multicolumn{2}{|c|}{ Number of alleles in ${ }^{(3)}$} & \multicolumn{2}{|l|}{ Heterozygosity in(4) } & \multirow[b]{2}{*}{$\begin{array}{l}\text { Primer sequence } \\
(\text { For }=\text { forward primer, Rev = reverse primer })^{(5)}\end{array}$} & \multirow{2}{*}{$\begin{array}{l}\text { GenBank } \\
\text { accession } \\
\text { no. }\end{array}$} \\
\hline & & & $\begin{array}{l}\text { Exoneura } \\
\text { nigrescens }\end{array}$ & $\begin{array}{l}\text { Exoneura } \\
\text { robusta }\end{array}$ & $\begin{array}{l}\text { Exoneura } \\
\text { nigrescens }\end{array}$ & $\begin{array}{l}\text { Exoneura } \\
\text { robusta }\end{array}$ & & \\
\hline N39 & $(\mathrm{TG})_{15}$ & $151 \mathrm{bp}$ & $9(n=10)$ & $8(n=10)$ & $0.700 / 0.789(n=10)$ & $1.000 / 0.868(n=10)$ & $\begin{array}{l}\text { For: 5'-CGCTTATCATATAAAACACTCGCTG-3' } \\
\text { Rev: 5'-TGTTTAAACGGAACCCATCGAATAC-3' }\end{array}$ & AY222387 \\
\hline N87 & $(\mathrm{CT})_{22}$ & $176 \mathrm{bp}$ & $1(n=4)$ & $4(n=3)$ & $-(6)$ & $1.000 / 1.000(n=3)$ & $\begin{array}{l}\text { For: 5'-ATATGGCTGCAGTAGAGTATTAAAGACC-3' } \\
\text { Rev: 5'-CTTCAACAAAAAGATAAGCAGAGAGAGAGA-3' }\end{array}$ & AY222405 \\
\hline N149 & $(\mathrm{CT})_{15}$ & $174 \mathrm{bp}$ & $7(n=4)$ & $7(n=8)$ & $0.750 / 0.964(n=4)$ & $0.500 / 0.792(n=8)$ & $\begin{array}{l}\text { For: 5'-CCTGCGATCCTCGATCGATTCC-3' } \\
\text { Rev: 5'-GGATCGGTGCCGTGCTTCTC-3' }\end{array}$ & AY222413 \\
\hline R1 & $(\mathrm{GT})_{25}(\mathrm{GA})_{10}$ & $193 \mathrm{bp}$ & $5(n=3)$ & $5(n=3)$ & $1.000 / 0.933(n=3)$ & $1.000 / 0.933(n=3)$ & $\begin{array}{l}\text { For: 5'-TATGCGTGTGCAGTGTATGTATATACG-3' } \\
\text { Rev: 5'-GTGCAGTGTGTTTACACATTCTTTCC-3' }\end{array}$ & AY222415 \\
\hline R76 & $(\mathrm{TC})_{19}$ & $244 \mathrm{bp}$ & $6(n=3)$ & $3(n=3)$ & $1.000 / 1.000(n=3)$ & $1.000 / 0.733(n=3)$ & $\begin{array}{l}\text { For: 5'-CGGAATTTCATACGAACATCTCACATC-3' } \\
\text { Rev: 5'-TTTGTACACTAAATGGTGCAACTGG-3' }\end{array}$ & AY222427 \\
\hline R145 & $(\mathrm{GA})_{11}$ & $165 \mathrm{bp}$ & $9(n=8)$ & $10(n=10)$ & $0.375 / 0.917(n=8)$ & $0.500 / 0.900(n=10)$ & $\begin{array}{l}\text { For: 5'-GTGCATCGTCCTTGATTCCTGC-3' } \\
\text { Rev: 5'-GCTGGAGAGCGTATGGTAAATGTTG-3' }\end{array}$ & AY222439 \\
\hline $\mathrm{N} 22^{(7)}$ & $(\mathrm{TC})_{19}(\mathrm{TA})_{11}$ & $141 \mathrm{bp}$ & $22(n=417)$ & $6(n=3)$ & $0.754 / 0.898(n=57)$ & $1.000 / 1.000(n=3)$ & $\begin{array}{l}\text { For: 5'-GTTTCTCGAAGGCGGCTAACTTC-3' } \\
\text { Rev: 5'-TCGCCTGTTAATTTCGCCGTAGG-3' }\end{array}$ & AY222381 \\
\hline $\mathrm{N} 60^{(7)}$ & $\begin{array}{l}(\mathrm{TC})_{4}(\mathrm{TA})_{2} \\
(\mathrm{TC})_{18}\end{array}$ & $187 \mathrm{bp}$ & $51(n=536)$ & $26(n=363)$ & $0.908 / 0.947(n=65)$ & $0.919 / 0.929(n=62)$ & $\begin{array}{l}\text { For: 5'-TTTCACTTTGCTGAAGACTTCGAAC-3' } \\
\text { Rev: 5'-CATAACTTCCAAGAAGATTTTCGGGAC-3' }\end{array}$ & AY222391 \\
\hline $\mathrm{N} 81^{(7)}$ & $\begin{array}{l}(\mathrm{CA})_{8} \mathrm{~A}(\mathrm{GC})_{8} \\
(\mathrm{AC})_{10}\end{array}$ & $188 \mathrm{bp}$ & $26(n=535)$ & $30(n=329)$ & $0.652 / 0.777(n=66)$ & $0.785 / 0.843(n=65)$ & $\begin{array}{l}\text { For: 5'-CTATTTCCTAACCTTTCCATCACACAC-3' } \\
\text { Rev: 5'-AATTCAATCCGATTGACAATGAGCC-3' }\end{array}$ & AY222402 \\
\hline N83(7) & $\begin{array}{l}(\mathrm{CG})_{4}(\mathrm{CA})_{14} \\
(\mathrm{TA})_{4}\end{array}$ & $265 \mathrm{bp}$ & $39(n=527)$ & $55(n=636)$ & $0.846 / 0.919(n=65)$ & $0.517 / 0.970(n=58)$ & $\begin{array}{l}\text { For: 5'-CAAGGGTATATACTATACTTCCGAAGGTT-3' } \\
\text { Rev: 5'-TTCTTGACCTATCCGAATCCAAATTCCT-3' }\end{array}$ & AY222403 \\
\hline $\mathrm{R} 32^{(7)}$ & $\begin{array}{l}(\mathrm{TC})_{6} \mathrm{C}(\mathrm{CT})_{9} \\
\mathrm{C}(\mathrm{CT})_{11}\end{array}$ & $310 \mathrm{bp}$ & $3(n=3)$ & $39(n=231)$ & $1.000 / 0.733(n=3)$ & $0.746 / 0.889(n=63)$ & $\begin{array}{l}\text { For: 5'-CTCACTTCGACTCCGGGGACA-3' } \\
\text { Rev: 5'-AAACGTCTAACAAGCGGGCTGA-3' }\end{array}$ & AY222417 \\
\hline $\mathrm{R} 74^{(7)}$ & $\begin{array}{l}(\mathrm{ATT})_{6} \mathrm{G}(\mathrm{TA})_{6} \\
(\mathrm{TG})_{9}\end{array}$ & $209 \mathrm{bp}$ & $40(n=528)$ & $53(n=363)$ & $0.823 / 0.966(n=62)$ & $0.922 / 0.953(n=64)$ & $\begin{array}{l}\text { For: 5'-AAGGAATAAATGGATGGGCTAAACG-3' } \\
\text { Rev: 5'-GTTAAAGAATCTCGAGTGAACATGG-3' }\end{array}$ & AY222426 \\
\hline R115(7) & $(\mathrm{CT})_{28}$ & $173 \mathrm{bp}$ & $6(n=8)$ & $26(n=353)$ & $0.875 / 0.817(n=8)$ & $0.738 / 0.847(n=65)$ & $\begin{array}{l}\text { For: 5'-CACGTAAATCTTCTACTAAATAACAGTCCC-3' } \\
\text { Rev: 5'-GACGCTCTCCCCCGATACACT-3' }\end{array}$ & AY222434 \\
\hline
\end{tabular}

(1) ' $\mathrm{N}$ ' loci are isolated from E. nigrescens, ' $\mathrm{R}$ ' from E. robusta strains.

(2) Sequenced clone allele.

(3) Number of different alleles found ( $n=$ number of sampled individuals that amplified).

(4) Observed $\left(H_{\mathrm{O}}\right)$ and expected $\left(H_{\mathrm{E}}\right)$ heterozygosity in the format: $H_{\mathrm{O}} / H_{\mathrm{E}}(n=$ number of sampled females). Values are calculated from Genepop version 3.1c (Raymond \& Rousset 1995) using one female chosen at random per nest.

(5) Forward primers were fluorescently labelled with either 6-FAM, HEX (Microsynth, Balgach, Switzerland) or NED (Perkin-Elmer, Hünenberg, Switzerland).

(6) Locus $\mathrm{N} 87$ amplified poorly in E. nigrescens. $H_{\mathrm{O}}$ and $H_{\mathrm{E}}$ can not be calculated since only one allele was found in this species.

(7) The primers for loci N22, N60, N81, N83 and R74 (in E. nigrescens), and for loci N60, N81, N83, R32, R74 and R115 (in E. robusta) are designed for simultaneous migration of their PCR products in a single lane of an ABI 377XL sequencer. These primer combinations were used for subsequent routine genotyping and hence show larger sample sizes. 
Prior to polymerase chain reaction (PCR), this solution was diluted 1:50 for E. nigrescens adults and pupae (no dilution for larvae and eggs) and 1:250 for E. robusta adults, pupae, larvae and eggs. Amplifications for both species were carried out in a $10 \mu \mathrm{L}$ reaction volume containing $5 \mu \mathrm{L}$ of template DNA solution and a final concentration of $0.05 \mathrm{U} / \mu \mathrm{L}$ Taq DNA polymerase (Qiagen, Oslo, Norway), $1 \times$ PCR buffer (Qiagen), $0.5 \mu \mathrm{M}$ of each primer, $300 \mu \mathrm{M}$ of each dNTP and $2.0 \mathrm{~mm} \mathrm{MgCl}_{2}$. All individual loci were amplified with a single touch-down PCR protocol: 4 min of denaturation at $94{ }^{\circ} \mathrm{C} ; 45$ cycles of 30 s at $94{ }^{\circ} \mathrm{C} ; 30$ s at $64^{\circ} \mathrm{C}$ $-0.2{ }^{\circ} \mathrm{C}$ / cycle (touchdown) and $2 \mathrm{~min}$ at $72^{\circ} \mathrm{C}$; and $5 \mathrm{~min}$ of final elongation at $72{ }^{\circ} \mathrm{C}$. In E. nigrescens, loci $\mathrm{N} 22$ and N81 (Table 1) were multiplexed using the same conditions except $1.5 \times$ PCR buffer (Qiagen), $0.3 \mu \mathrm{M}$ of each primer and $2.25 \mathrm{~mm} \mathrm{MgCl}_{2}$. In this case, cycling conditions were 4 min of denaturation at $94{ }^{\circ} \mathrm{C} ; 45$ cycles of $30 \mathrm{~s}$ at $94{ }^{\circ} \mathrm{C}$; $30 \mathrm{~s}$ at $61^{\circ} \mathrm{C}-0.2{ }^{\circ} \mathrm{C} /$ cycle (touchdown) and $2 \mathrm{~min}$ at $68{ }^{\circ} \mathrm{C}$; and $5 \mathrm{~min}$ of final elongation at $68^{\circ} \mathrm{C}$. We used Perkin-Elmer 9700 GeneAmp, MJ Research PTC-100 96 V and Biometra T Gradient thermocycling machines for PCR amplifications.

We selected a subset of the developed microsatellite loci for each species (loci N22, N60, N81, N83 and R74 for E. nigrescens; loci N60, N81, N83, R32, R74 and R115 for $E$. robusta) based on their variability and product sizes (Table 1). These loci can be analysed in a single lane on an ABI 377XL sequencer, and showing 22-55 alleles per locus, they allow quick and accurate determination of pedigrees, reproductive skew and relatedness in colonies. The loci in these subsets show no significant genotypic linkage disequilibrium, with the exception of N81 vs. R32 in E. robusta $(P=0.002$ with a probability threshold of 0.003 after Bonferroni corrections; Raymond \& Rousset 1995). Observed heterozygosities $\left(H_{\mathrm{O}}\right)$ in the subsets were lower than expected heterozygosities $\left(H_{\mathrm{E}}\right)$ (Table 1$)$, but significant deviations from Hardy-Weinberg equilibrium occurred only at loci N22 and R74 in E. nigrescens and at loci N81, N83 and R32 in E. robusta (exact Hardy-Weinberg test after Bonferroni corrections; Raymond \& Rousset 1995). These deviations and the observed linkage disequilibrium can be explained by the presence of extensive family groups within the sampled populations (containing sister individuals sired by the same haploid male). The marked difference between $H_{\mathrm{O}}$ and $H_{\mathrm{E}}$ at locus N83 in E. robusta suggests that there might be null alleles (Table 1).

The 13 microsatellite primers presented here, as well as the 50 additional microsatellite sequences published on GenBank, provide valuable tools for genetic investigations in Allodapine bees.

\section{Acknowledgements}

We thank Dr Katja Hogendoorn for collections of native Australian Exoneura and Dr Rob Hammond for helpful comments on the manuscript. This work was supported by grants from the Swiss National Science Foundation.

\section{References}

Cronin AL (2001) Social flexibility in a primitively social allodapine bee (Hymenoptera: Apidae): results of a translocation experiment. Oikos, 94, 337-343.

Estoup A, Turgeon J (1996) Microsatellite markers: Isolation with non-radioactive probes and amplification. Protocols available by WEB at the address http://www.inapg.inra.fr/dsa/microsat/ microsat.htm

Gerber S, Mariette S, Streiff R, Bodénès C, Kremer A (2000) Comparison of microsatellites and amplified fragment length polymorphism markers for parentage analysis. Molecular Ecology, 9, 1037-1048.

Giegerich R, Meyer F, Schleiermacher C (1996) GeneFisher - Software Support for the Detection of Postulated Genes. Proceedings of the Fourth International Conference on Intelligent Systems for Molecular Biology. AAAI Press, 68-77.

Raymond M, Rousset F (1995) GENEPoP Version 1.2.: Populationgenetics software for exact tests and ecumenicism. Journal of Heredity, 86, 248-249.

Reeve HK, Keller L (2001) Tests of reproductive-skew models in social insects. Annual Review of Entomology, 46, 347-385.

Schwarz MP, Bull NJ, Hogendoorn K (1998) Evolution of sociality in the allodapine bees: a review of sex allocation, ecology and evolution. Insectes Sociaux, 45, 349-368. 